\title{
FUNGAL FLORA OF THE DIGESTIVE TRACT OF RHODNIUS PROLIXUS, RHODNIUS NEGLECTUS, DIPTELANOGASTER MAXIMUS AND PANSTRONGYLUS MEGISTUS, VECTORS OF TRYPANOSOMA CRUZI, CHAGAS, 1909
}

\author{
Aurea Maria Lage de Moraes ${ }^{1 *}$; Angela Cristina Vieira Junqueira ${ }^{2}$; Valéria Celano ${ }^{2}$; Gisela Lara da Costa ${ }^{1}$; \\ José Rodrigues Coura ${ }^{2}$
}

\author{
${ }^{1}$ Departamento de Micologia, Instituto Oswaldo Cruz, Rio de Janeiro, RJ, Brasil; ${ }^{2}$ Departamento de Medicina Tropical, Instituto \\ Oswaldo Cruz, Rio de Janeiro, RJ, Brasil
}

Submitted: August 13, 2003; Returned to authors for corrections: April 07, 2004; Approved: October 04, 2004

\begin{abstract}
This paper reports a study on the mycobiota in the digestive tract of four important species of triatomines: Rhodnius prolixus, R. neglectus, Diptelanogaster maximus and Panstrongylus megistus. The digestive tracts of 90 adults and 425 nymphs of these four triatomine species were studied and 365 fungal strains were isolated. The genera with the greatest number of species were Aspergillus, Penicillium (14 species in each genus), Acremonium and Cladosporium (three species in each genus), and the most frequent species, in decreasing order, were Aspergillus awamori, Penicillium corylophilum, Cladosporium herbarum and Aspergillus niger. It was concluded that, among the isolated fungi, Aspergillus niger and Penicillium corylophilum might be part of the natural flora of the digestive tract of triatomines.
\end{abstract}

Key words: Aspergillus spp, fungi, insect's digestive tract, mycoflora, Penicillium spp, triatomines

\section{INTRODUCTION}

Chagas disease or American trypanosomiasis constitutes a major public health problem in Latin America. The disease is widespread from the southern USA to Argentina and Chile, with great importance in Brazil. It is an infection caused by the protozoan parasite Trypanosoma cruzi (Chagas, 1909) and transmitted mainly via fecal droppings of triatomine bugs. The infection affects approximately five million people in Brazil (8) and 16 to 18 million people in Latin America (23).

The association with a microbial flora in the digestive tracts of several insect groups, such as Lepidoptera, Coleoptera, Isoptera, among others, is widely exemplified by studies of insect-fungus interactions $(15,16,17,36)$. Furthermore, a wide variety of bloodsucking arthropods, among these the triatomines $(11,28)$, have been reported to contain symbiotic microorganisms.
So far, the importance of insect-fungus interactions in the development of T. cruzi in the digestive tract of the vector has not been investigated. However, Dias (7) and Jandin (18) suggested that the presence of bacteria in the digestive tract of adult triatomines and nymphs could reduce $T$. cruzi infections in the species $P$. megistus, $R$. prolixus and Triatoma infestans. Moraes and coworkers (27), in a study on nymphs of $P$. megistus used in xenodiagnostic tests, speculated that perhaps the presence of fungi in the intestinal tract of triatomines has an influence on T. cruzi colonization.

Based on the need for more knowledge of this fungal flora, we published data on the mycoflora in the digestive tract of five important species of triatomines (Triatoma infestans, $T$. brasiliensis, T. pseudomaculata, T. sordida and T. vitticeps) (24). In this paper, we have expanded the work including other four species with the objective to establish the natural fungal flora of these triatomines and to search for the occurrence of

*Corresponding author. Mailing address: Departamento de Micologia, Pav. Leônidas Deane, 6ªndar, Sala 606. Av. Brasil, 4365, Manguinhos, 21045-900, Rio de Janeiro, RJ, Brasil. Tel.: (+5521) 3865-8208. Fax: (+5521) 3865-8113. E-mail: aurea@ioc.fiocruz.br 
fungi that are pathogenic to humans or present potential use as biological control agents.

\section{MATERIALS AND METHODS}

\section{Insects}

Adults and nymphs of four species of laboratory-raised triatomines, Rhodnius prolixus, R. neglectus, Panstrongylus megistus and Dipetelanogaster maximus, and sylvan specimens of $P$. megistus and $R$. neglectus were studied. The lab-raised insects were provided by the Triatomine Laboratory of the Department of Tropical Medicine of the Institute Oswaldo Cruz - FIOCRUZ, and the captured specimens of P. megistus and $R$. neglectus were kindly provided by Dr. Tereza Cristina M. Gonçalvez, Department of Entomology - FIOCRUZ. The insects were divided into three classes of samples: 1- a pool of 10 adult insects, separated by sex; 2- four insects treated individually; and 3- a pool of 20 nymphs at each developmental stage. In total, there were 80 adult insects and 400 nymphs.

The sylvan insects, collected in the states of Minas Gerais and Goiás, were divided into two types of samples: 1- a pool of 10 adult insects and 2- a pool of 5 nymphs, totalizing 10 adults and 10 nymphs of $R$. neglectus and 15 nymphs of $P$. megistus.

\section{Dissection procedure}

In order to prepare the pool, healthy adults that had not been fed for 14 days were selected. These were then sacrificed with chloroform in a laminar-flow chamber and submitted to washes and dissected as described by Moraes et al. (24). The same procedures were used for the individual samples and for the triatomines collected in the field.

\section{Material culturing and identification}

The macerated samples were processed according to Lachaise et al. (21) and Moraes et al. (24) and $0.2 \mathrm{ml}$ of each dilution was seeded in Petri dishes containing the following culture media, to which chloranphenicol (Sigma) was added: PDA(Potato Dextrose Agar - Difco); MEYA [ Malt extract (Difco), Yeast extract (Pro-Analysi) and Agar (Merck)] and YPGA [Yeast extract, Peptone (Difco), Glucose (Merck) and Agar]. Thereupon, they were incubated at room temperature $\left( \pm 28^{\circ} \mathrm{C}\right)$.

Analyses of growth and counts were carried out daily during the first 10 days. Thereafter, the examinations were conducted every 3 days until the $21^{\text {st }}$ day. The isolated colonies were seeded in PDA and malt extract medium for identification, according to the procedures reported by Barnett and Hunter (2), Barron (3), Kendrick et al. (20) and McGinnis (22). Growth rates of the colonies were measured according to the specific literature using a Mitutoyo digimatic caliper with $0.01 \mathrm{~mm}$. The microscopic characteristics were studied using the micro-culture technique (33). The material was mounted in $\mathrm{KOH}$ for observation of dark fungal specimens and in Amann lactophenol-cotton blue for observation of other representatives, and examined under a Nikon optical microscope (Labophot model). All measurements are given as the average of 50 of each structure observed. Species identification was carried out according to Ellis $(12,13)$, Pitt (30,31), Raper and Fennell (32), Christensen et al. (4-6), Samson (34,35), Gams (14), Domsch et al. (9), Klich and Pitt (19).

The strains considered of interest were preserved in PDA under mineral oil and were incorporated into the Fungi Culture Collection of the Department of Mycology - FIOCRUZ (IOC).

\section{RESULTS}

The digestive tracts of 90 adults and 425 nymphs of triatomines were studied and, based on differences among the samples, 365 fungal strains were isolated; among those 156 were isolated from Panstrongylus megistus (42\%); 104 from $R$. prolixus (29\%); 53 from $R$. neglectus (14.5\%) and 52 from $D$. maximus (14.5\%). All culture media used were equally effective for fungi isolation. The Petri dishes used as contamination controls showed no fungal growth.

Sterile mycelia were present in the isolated specimens, and after being seeded in sporulation-inducing media, many remained sterile and were classified as Mycelia sterilia. The other isolated specimens were classified into 15 genera and 47 species.

The genera with greater number of species were Penicillium, Aspergillus (14 species in each genus), Acremonium and Cladosporium (three species in each genus). The most frequent species, in decreasing order, were Aspergillus awamori, Penicillium corylophilum, Cladosporium herbarum and Aspergillus niger.

\section{DISCUSSION}

A wide variety of bloodsucking arthropods has been reported to contain symbiotic microorganisms (28), but obligatory commensalisms or mutualism can only be suspected if the first experimental approach reveals a consistent microbial flora.

A number of investigators had tried to study this flora, but none of them could prove the origin of colonization of labraised insects. Nyirady (28) reared germ free triatomines and reported slight differences in their developmental periods when compared with those of the control group. Thus, fungi colonization of lab-raised triatomines could be due to external factors, such as air contamination or feeding contamination.

All the fungi isolated in the present study are widely spread in nature. As we observed in a previous work with other five triatomine species (24), the genera Aspergillus and Penicillium are the most frequent. This fact was also observed with $P$. megistus, R. prolixus, R. neglectus and D. maximus. Based on this observation, we can conclude that Aspergillus niger and Penicillium corylophilum might be part of the natural flora of 
the digestive tracts of these eight species studied, since these two fungal species were found in all of them and almost during all developmental stages.

Aspergillus niger and Penicillium corylophilum are frequently reported to have the most varied associations with insects $(10,24)$ and are regarded as entomopathogenic $(1,25)$. The specimens belonging to the genus Acremonium also deserve some attention, since they were frequent in these four triatomine species and in the other five species previously studied; and the genus is not common in other insect orders. However, A. niger, P. corylophilum and the species of the genus Acremonium have not been found in the digestive tracts of $P$. megistus nymphs infected with $T$. cruzi (25). This observation leads us to the suggestion that these fungi could be used as a barrier to the protozoan colonization.

The present study constitutes a new record, since Aspergillus flavipes, Curvularia trifolli, Humicola fuscoatra, Macrophoma sp., Penicillium chrysogenum, Penicillium herquei, Penicillium miczinskii, Trichoderma aureoviride and Rhinocladiella atrovirens have never been reported in association with triatomines.

Despite the fact that Dematiaceous fungi, specially the genus Cladosporium, are plant-associated, a great number of specimens of this genus could be isolated. This fact might be related to the natural habitats of the triatomines (e.g. trees, palms).

Although the triatomine physiology contributes to colonization and establishment of fungal populations, the relative frequencies of fungi were low (data not shown) and differences in susceptibility to fungal colonization were observed among the four species studied. Panstrongylus megistus showed to be the most susceptible species to fungus colonization, as it is also the most susceptible to T. cruzi colonization (29). Surprisingly, Rhodnius prolixus showed a great susceptibility to fungal colonization, although it has a faster metabolism. D. maximus and $R$. neglectus showed lower susceptibility.

Further studies using more triatomine species are needed to define a constant fungal flora. Additional molecular analysis (e.g. ITS sequencing), using in vitro and in vivo models with germ-free insects, would allow to study the type of association between fungi and insects, and the possible role of fungi as a barrier to protozoan colonization, since Moraes and coworkers (27) observed a great reduction in the fungal population in the gut of triatomines infected with T. cruzi.

\section{ACKNOWLEDGMENTS}

We would like to thank Ms Maria Inez de Moura Sarquis and Ms Andrea Carbone for helpful assistance during the execution of this study and to the Conselho Nacional de Desenvolvimento Científico e Tecnológico (CNPq) for financial support.

\section{RESUMO}

\section{Flora fúngica do trato digestivo de Rhodnius prolixus, Rhodnius neglectus, Diptelanogaster maximus e Panstrongylus megistus vetores de Trypanosoma cruzi, Chagas 1909}

Um estudo da micobiota do trato digestivo de quatro importantes espécies de triatomíneos, Rhodnius prolixus, $R$. neglectus, Diptelanogaster maximus e Panstrongylus megistus, foi realizado. Foram examinados os tratos digestivos de 90 adultos e 425 ninfas destas espécies de triatomíneos e 365 cepas fúngicas foram isoladas. Os gêneros com o maior número de espécies encontradas foram Aspergillus, Penicillium (14 espécies cada), Acremonium e Cladosporium (3 espécies cada) e as espécies mais freqüentes, em ordem decrescente, foram Aspergillus awamori, Penicillium corylophilum, Cladosporium herbarum e Aspergillus niger. Dentre os fungos isolados, concluímos que Aspergillus niger e Penicillium corylophilum possam fazer parte da flora natural do trato digestivo destes triatomíneos.

Palavras-chave: Aspergillus spp., fungos, trato digestivo de insetos, micoflora, Penicillium spp., triatomineos

\section{REFERENCES}

1. Alves, S.B. Controle Microbiano de Insetos. Mande, São Paulo, 1986, 415pp.

2. Barnett, H.L.; Hunter, B.B. Illustrated genera of imperfect fungi. Burgess Publishing Company, California, 1972, 420pp.

3. Barron, G.L. The genera of Hyphomycetes from soil. Robert E. Krieger Publishing Co., New York, 1977, 320pp.

4. Christensen, M.; Raper, K.B. Aspergillus robustus, a new specie in the Aspergillus ochraceus group. Mycologia, 70:200-205, 1978.

5. Christensen, M. A synoptic key and evaluation of species in the Aspergillus flavus group. Mycologia, 73:1056-1084, 1981.

6. Christensen, M. The Aspergillus ochraceus group: Two new species from western soils and a synoptic key. Mycologia, 74:210-225, 1982.

7. Dias, E. Sobre a presença de symbiontes em Hemípteros hematófagos. Mem. Inst. Oswaldo Cruz, 32:165-168, 1937.

8. Dias, J.C.P. Epidemiology of Chagas disease. In: Wendel et al., eds. Chagas Disease (American Trypanosomiasis): It's impact on transfusion and clinical medicine. Sociedade Brasileira de Hematologia e Hemoterapia, São Paulo, 1992, pp.49-80.

9. Domsch, K.H.; Gams, W.; Trante-Heidi, A. Compendium of soil fungi. Lubrecht \& Cramer Ltd., New York, 1995, 340pp.

10. Dubrovskiy, Y.V.; Rybal-Chenko, V.M. Entompathogenic forms in the mycoflora of habitats of Aedes geniculatus larvae. Entomol. Rev., 71:40-41, 1993.

11. Duncan, J.T. On bactericidal principle present in the alimentary canal of insects and arachnides. Parasitol., 18:238-252, 1926.

12. Ellis, M.B. Dematiaceus Hyphomycetes. CAB Press, London, 1971, $123 \mathrm{pp}$.

13. Ellis, M.B. More Dematiaceus Hyphomycetes. CAB Press, London, 1976, 116pp.

14. Gams, W. Cephalosporium-like Hyphomycetes: some tropical species. Trans. Br. Mycol. Soc., 61:389-404, 1975. 
15. Gilliam, M.; Prest, D.B. Fungi isolated from the contents of foraging worker honey bees, Apis mellifera. J. Invertebr. Pathol., 20:101103, 1972.

16. Gilliam, M.; Prest, D.B. The mycoflora of selected organs of queen honey Apis. mellifera. J. Invertebr. Pathol., 29:235-237, 1977.

17. Ismail, M.A.; Abdel-Sater, M.A. Fungi associated with Egyptian cotton leafworm Spodoptera littoralis Boisdoval. Mycopathol., 124:79-86, 1993.

18. Jandin, J. Du rôle des bactéries dans le tube digestif des insectes vecteurs des plasmodidae et des trypanosomidae. Ann. Soc. Belgium Med. Trop., 47:331-342, 1967.

19. Klich, M.A.; Pitt, J.I. A laboratory guide to common Aspergillus species and their teleomorphs. CSIRO, Australia, 1994, 116pp.

20. Kendrick, W.B.; Carmichel, J.W.; Conners, J.L.; Sigler, L. Genera of Hyphomycetes. The University of Alberta Press, Canada, 1980, $328 \mathrm{pp}$.

21. Lachaise, D.; Pignal, M.C.; Ronault, J. Yeast flora partitioning by Drosophilids species inhabiting a tropical African savanna of Ivorycoast. Ann. Soc. Entomol. Fr., 15:659-680, 1979.

22. McGinnis, M.R. Laboratory handbook of medical mycology. Academic Press, New York, 1980, 286pp.

23. Moncayo, A. Chagas' Disease. UNDP World Bank WHO Special Programme for Research and Training in Tropical Disease (TDR). Tropical Disease; Progress in International Research, Geneva: 6775 (Programme Report, 11), 1993.

24. Moraes, A.M.L.; Junqueira, A.C.V.; Costa, G.L.; Celano, V.; Oliveira, P.C.; Coura, J.R. Fungal flora of the digestive tract of 5 species of triatomines vectors of Trypanosoma cruzi Chagas 1909. Mycopathol., $151: 41-48,2000$

25. Moraes, A.M.L.; Corrado, M.; Holanda, V.L.; Costa, G.L.; Ziccardi, M.C.B.; Lourenço-de-Oliveira, R.; Oliveira, P.C. Aspergillus from Brazilian mosquitoes - I. Genera Aedes and Culex from Rio de Janeiro state. Mycotaxon., 88:413-422, 2001.
26. Moraes, A.M.L.; Costa, G.L.; Ziccardi, M.C.B.; Lourenço-de-Oliveira, R.; Oliveira, P.C. The entomopathogenic potential of Aspergillus spp. in mosquitoes vectors of tropical diseases. J. Basic. Microbiol., 41:45-49, 2001.

27. Moraes, A.M.L.; Figueiredo, A.R.; Junqueira, A.C.V.; Costa, G.L.; Aguiar, R.K.; Oliveira, P.C. Fungal flora of the digestive tract of Panstrongylus megistus (Reduviidae) used for experimental xenodiagnosis of Trypanosoma (Schizotripanum) cruzi Chagas 1909. Rev. Iberoam. Micol., 18:79-82, 2001.

28. Nyirady, S.A. The germfree culture of three species of Triatominae: Triatoma protracta (Uhler), Triatoma rubida (Uhler) and Rhodnius prolixus Stal. J. Med. Entomol., 10:417-448, 1973.

29. Perlowagora-Szumlewicz, A.S.; Muller, C.A.; Moreira, C.J.C. Studies in search of a suitable experimental insect model for xenodiagnosis of hosts with Chagas' disease. 3- On the interaction of vectors species and parasite strain in the reaction of bugs to infection by T.cruzi. Rev. Saúde Pub. São Paulo, 22:390-400, 1988.

30. Pitt, J.I. The genus Penicillium. Academic Press, Sydney, 1979, $423 \mathrm{pp}$.

31. Pitt, J.I. A laboratory guide to common Penicillium species. Academic Press, New York, 1985, 147pp

32. Raper, K.B.; Fennell, D.I. The genus Aspergillus. The Williams \& Wilkins Co., Baltimore, 1965, 386pp.

33. Rivalier, E.; Seydel, S. Nouveau procedé de culture sur lames gélosées appliqué létude microscopique des champignons deteignes. Ann. Parasitol., 10:444-452, 1932.

34. Samson, R.A. Paecilomyces and some allied Hyphomycetes. Studies in Mycology, 6:1-119, 1974.

35. Samson, R.A. A compilation of the Aspergilli described since 1965. Studies in Mycology, 18:1-38, 1979.

36. Schlein, Y.; Polachek, I.; Yuval, B. Mycoses, bacterial infections and antibacterial activity in sandflies and their possible role in the transmission of Leishmaniosis. Parasitology, 90:57-66, 1985. 